\title{
Occurrence of the Myoid Cell in the Harderian Gland of the Japanese Colubrid Snake, Rhabdophis tigrinus
}

\author{
Sumio YoshIE and Tatsuyuki Ogawa \\ Department of Oral Anatomy (Prof. T. Ogawa), Nippon Dental University, Niigata, Japan
}

Received October 22, 1982

Summary. An electron microscope study of the Harderian gland of the snake, Rhabdophis tigrinus, revealed the occurrence of a myoid cell in the glandular body.

The myoid cell, in oval profile, is located in the perivascular space and enveloped by a basement membrane. The plasma membrane of the cell is studded with a number of vesicular caveoli. The myoid cell cytoplasm is largely occupied by myofilaments which do not form discrete bundles of myofibrils. The striations comprise the $A$ and $I$ bands together with $\mathrm{Z}$ lines, but neither an $M$ nor an $H$ zone is detectable. Although the transverse tubule appears to be scarce, the sarcoplasmic reticulum is well developed. No triadic configuration is observed. The cytoplasm includes a few numbers of mitochondria, sarcoplasmic reticulum, fat droplets, dense membrane-bound granules and free ribosomes. The histological characteristics of the present myoid cell are compared to those of identical cells commonly existing in the thymus.

Myoid cells resembling striated muscle fiber are frequently encountered in animal and human thymuses and have been studied by both light and electron microscopy (BARGMANN, 1943; VAn De Velde and Friedman, 1966; Raviola and Raviola, 1967; Bockman and WinBorn, 1967, 1969; ITo, Hoshino and ABE, 1969). As for other organs, the myoid cells or striated muscle fibers have also been reported in the human thyroid gland (Mori, 1953) and in the cattle pineal body (Makimura and Miyake, 1954).

During the course of the ultrastructural examination of the Harderian gland-a type of ocular gland-of the Japanese colubrid snake, Rhabdophis tigrinus, a myoid cell was encountered in the glandular body. The first detailed description of the ocular gland of the snake was by Meckel (1826), who introduced the name "Thränendrüse." It was then renamed the Harderian gland (SMith and Bellairs, 1947), which has since been generally employed (see TAuB, 1966).

It appears that the myoid cell or striated muscle fiber has never been reported in the Harderian gland of the snake. This paper demonstrates the presence of the myoid cell in the Harderian gland, and compares its histological characteristics with those of identical cells which have been long known to exist in the thymus.

\section{MATERIALS AND METHODS}

The snake, Rhabdophis tigrinus, possessing the myoid cell in the Harderian gland was an adult female of $105 \mathrm{~cm}$ in length. 
The snake was anesthetized with ethyl ether, and perfused via the left carotid artery with $0.8 \%$ sodium chloride and successively with $2.5 \%$ glutaraldehyde in $0.1 \mathrm{M}$ phosphate buffer, $\mathrm{pH}$ 7.4. The fixed gland was removed, minced into small pieces and immersed in the same fixative for $2 \mathrm{hrs}$ at room temperature. After washing in the buffer, the tissue blocks were post-fixed in $2 \%$ osmium tetroxide in the same buffer for 2 hrs, dehydrated in graded ethanol and embedded in Epon 812. Ultrathin sections were cut on an LKB ultra-microtome, stained in uranyl acetate and Reynolds' lead, and examined with a Hitachi $\mathrm{H}-500$ electron microscope.

Light microscopic examination was also performed on $1 \mu \mathrm{m}$ thick sections of the Epon embedded blocks, stained with toluidine blue.

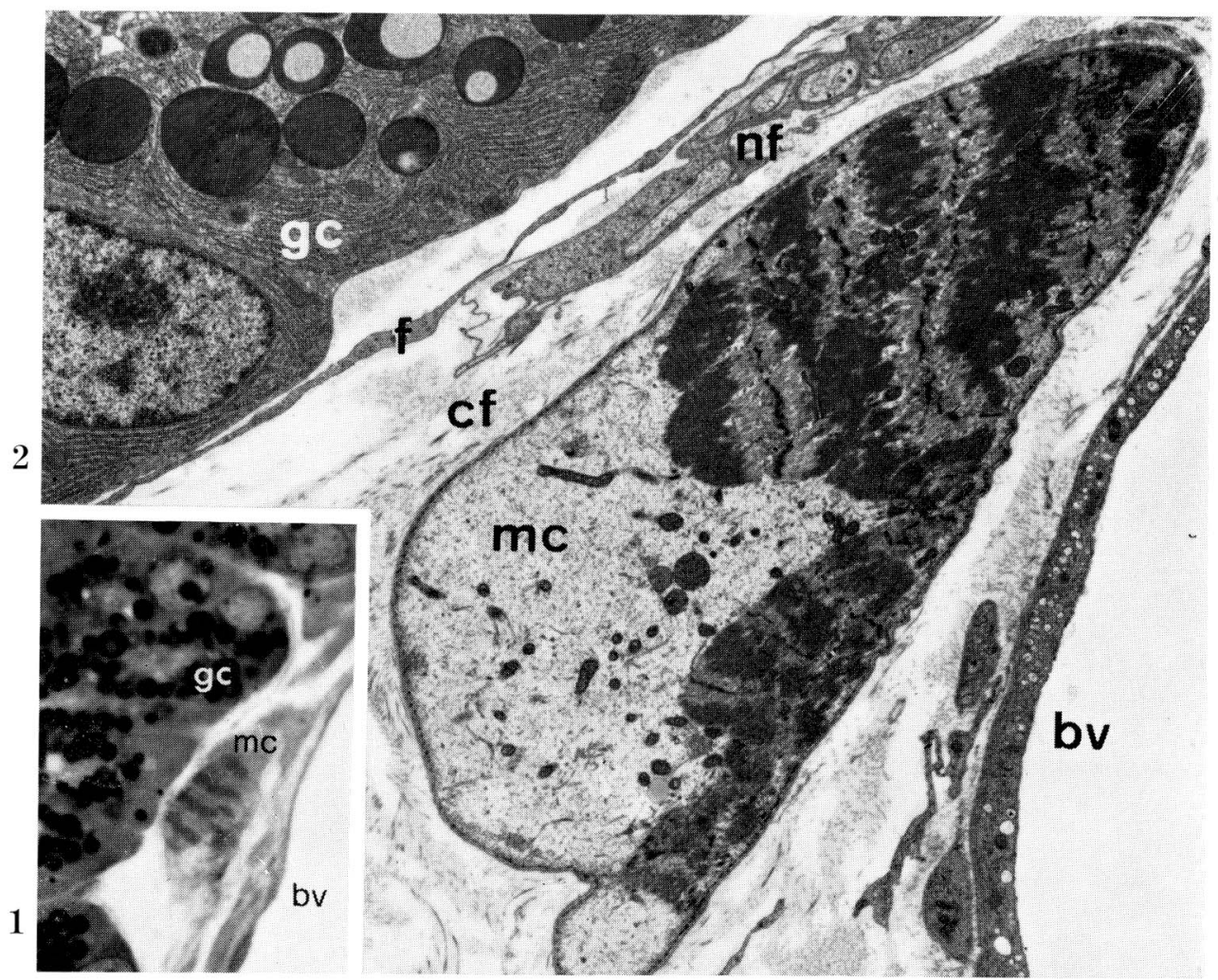

Fig. 1. Light micrograph of the myoid cell $(m c)$ occurring in the perivascular space of the Harderian gland. Light and dark stripes are visible in the cell. One micron Epon section is stained with toluidine blue. $b v$ Blood vessel, $g c$ Harderian gland cell. $\times 1,100$

Fig. 2. Low-power electron micrograph of the myoid cell $(m c)$. The myofibrils in no definite bundle formation offer prominent striation. Surrounding the myoid cell are seen collagen fibers ( $c f$ ), fibroblasts $\left(f^{\prime}\right)$ and nerve fibers ( $\left.n f\right)$. $\quad b v$ Blood vessel, $g c$ Harderian gland cell. $\times 5,000$

Fig. 3. a-c. A closer view of the myoid cell. The cell is enveloped in a basement membrane $(\mathrm{bm})$. Vesicular caveoli (thick arrow) stud the plasma membrane, to which dense bodies (thin arrow) are attached. In the myofibril, $A(A)$ and $\mathrm{I}(I)$ bands, $Z(Z)$ lines are prominent. The sarcoplasmic reticulum $(s r)$ is branched in a network around the $Z$ line and unbranched or glomerular in the myofibril and cytoplasm. The transverse tubule $(t)$ is located at the periphery of the A band. The cytoplasm also possesses polysomes ( $p$ ), dense membranebound granules $(d g)$, mitochondria $(m)$ and fat droplet $(o d)$. a and $\mathrm{c}: \times 18,000, \mathrm{~b}: \times 21,000$ 

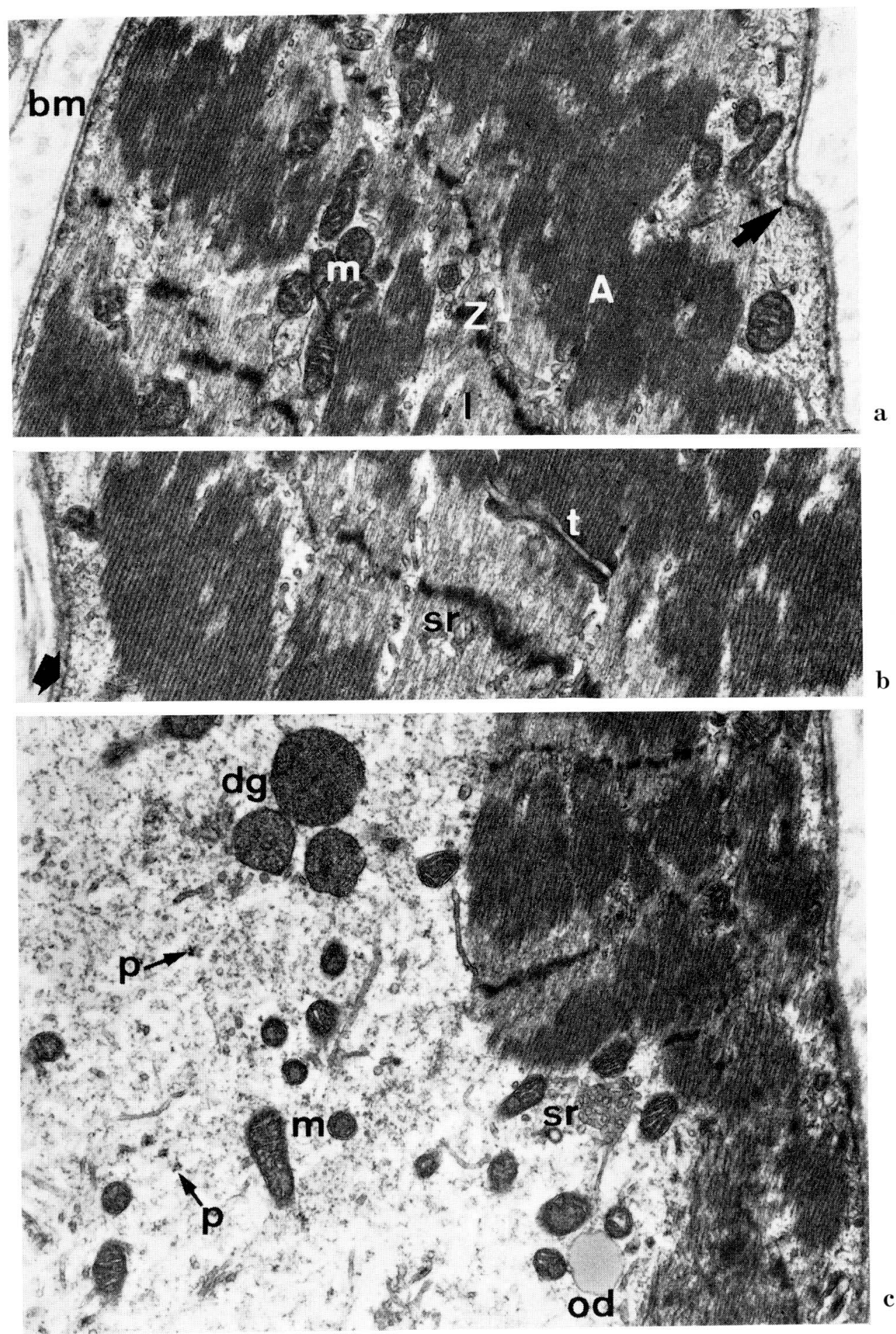

Fig. 3. Legend on the opposite page. 


\section{RESULTS AND DISCUSSION}

A single myoid cell occurs in the perivascular space in the posterior portion of the Harderian gland. The myoid cell is oval in profile and shows light and dark stripes under the light microscope (Fig. 1). The perivascular space holding the cell is loosely filled with collagen fibers. Fibroblasts and nerve fibers invested with the Schwann cell also exist in the vicinity of the myoid cell (Fig. 2). No nerve fiber was identified as contacting the plasma membrane of the myoid cell.

The myoid cell is entirely enveloped in a basement membrane of uniform thickness (Fig. 3a). The plasma membrane of the cell is randomly studded with a number of vesicular caveoli (Fig. 3b). The dense body-like structures are also distributed throughout the peripheral cytoplasm and attached to the plasma membrane (Fig. 3a). The existence of both vesicular caveoli and dense bodies, which characterize the smooth muscle fiber, is not clearly shown in the thymic myoid cell (RAviola and Raviola, 1967; Ito, Hoshino and Abe, 1969).

The profiled myoid cell has half or more of its area of cytoplasm occupied by the myofilaments (Fig. 2). However, myofilaments do not build up the diecrete bundles of myofibrils as they generally do in the skeletal muscle fiber (Fig. 2, 3a). They are quite similar to those of the cardiac muscle fiber. The myofibrils are composed of both thick and thin filaments, which are oriented in the longer axis direction of the cell profile (Fig. 3a-c). Both the $\mathrm{A}$ and $\mathrm{I}$ bands, and the $Z$ lines are prominent, but neither an $\mathrm{M}$ nor an $\mathrm{H}$ zone is detectable in the myofibrils (Fig. 2, 3a). The profiled boundary between the A and I bands is not smooth, but notchy (Fig. 3a). The $Z$ lines are often intercepted by sarcoplasmic reticulum (=agranular endoplasmic reticulum) and/or cytoplasm (Fig. 3a, b). In the thymic myoid cells of the animal and the human, myofilaments tend to make discrete bundles of myofibrils, which are oriented in various courses (Raviola and Raviola, 1967; Bockman and Winborn, 1969; Ito, Hoshino and AвE, 1969). Although most myoid cells possess both thick and thin filaments, myoid cells with very few or totally lacking thick filaments have been reported in the turtle thymus (RAviola and Raviola, 1967) and in the human thymus (Ito, Hoshino and ABe, 1969).

The transverse tubule ( $\mathrm{T}$ system), though rarely appearing, is located at the periphery of the A band (Fig. $3 \mathrm{~b}$ ). On the other hand, the sarcoplasmic reticulum is welldeveloped and encountered mostly within the I bands, in which they branch in a network around the $Z$ lines (Fig. 3a, b). No triadic configuration is observed. In the thymic myoid cell, the membranous components of the sarcoplasmic reticulum and the $T$ system are commonly found throughout the interfibrilar cytoplasm; triadic configurations are also distributed but tend to bear no consistent topographical relation with the sarcomere (RAviola and Raviola, 1967; Ito, Hoshino and Abe, 1969).

The cytoplasm occupying a large area of the cell profile offers a clear appearance, and includes a few mitochondria, sarcoplasmic reticulum, fat droplets, dense membranebound granules, and free ribosomes (Fig. 2, 3c). The mitochondria, with relatively dark matrices are scattered in the cytoplasm, and are often associated with the fat droplets (Fig. 3c). The free ribosomes are scarce in number and frequently appear arranged in polysomes (Fig. 3c). Although the major part of the sarcoplasmic reticulum is unbranched, complicated branches, glomerular in structure, can also be detected (Fig. 3c).

The thymic myoid cells of the animal are generally classified into three stages or 
types, according to their fine structure: adult, embryonal and anomalous muscle cells (RAVIOLA and RAviola, 1967), or mature, immature and degenerating cells (BockMAN and WinBorn, 1967). Among these, the embryonal or immature cell resembles the developing skeletal and cardiac muscle fibers, and shows plentiful cytoplasm containing tubules, mitochondria, glycogen granules, and ribosomes often arranged in helices and rosettes (Raviola and Raviola, 1967). Application of these facts to the present results suggests that the myoid cell of the Harderian gland may be in a rather immature stage.

Although the nucleus of the present myoid cell can not be observed, each thymic myoid cell contains a single nucleus located either centrally or eccentrically (RAvioLA and RAviola, 1967).

No innervation of the thymic myoid cells was demonstrated (RAviola and RAviola, 1967). Furthermore, the functions of the cell remain obscure.

Acknow ledgments. We wish to thank Prof. T. Fujita, Department of Anatomy, Niigata University School of Medicine, and Prof. H. Fujita, Department of Anatomy, Osaka University Medical School, for their valuable comments and encouragement during the course of this work.

\section{REFERENCES}

Bargmann, W.: Der Thymus. In: Möllendorff's Handbuch der mikroskopischen Anatomie des Menschen, VI/4. Springer, Berlin, 1943.

Bockman, D. E. and W. B. Winborn : Electron microscopy of the thymus in two species of snakes, Crotalus atrox and Lampropeltis getulus. J. Morphol. 121: 277-294 (1967). : Ultrastructure of thymic myoid cells. J. Morphol. 129: 201-210 (1969).

Ito, T., T. Hoshino and K. Abe: The fine structure of myoid cells in the human thymus. Arch. histol. jap. 30: 207-215 (1969).

Makimura, F. and M. Miyake: Striated muscle fibers in the pineal body. Arch. histol. jap. 6: 433435 (1954).

Meckel, J. F.: Ueber die Kopfdrüsen der Schlangen. Arch. Anat. Physiol. 9: 1-13 (1826).

Mori, M.: Skeletal muscle fiber in thyroid. Arch. histol. jap. 4: 229-230 (1953).

Raviola, E. and G. Raviola : Striated muscle cells in the thymus of reptiles and birds: An electron microscopic study. Amer. J. Anat. 121: 623-646 (1967).

Smith, M. and A. d'A Bellairs: Head glands of snakes, with remarks on the evolution of the parotid gland and teeth of the Opisthoglypha. J. Linn. Soc. (Zool.) 41: 351-368 (1947).

Taub, A. M.: Ophidian cephalic glands. J. Morphol. 118: 529-542 (1966).

Van de Velde, R. L. and N. B. Friedman: The thymic "Myoidzellen" and myasthenia gravis. J Amer. Med. Assoc. 198: 287-288 (1966).

\author{
吉江 紀夫 \\ 干951 新潟市浜浦町 1-8 \\ 日本歯科大学新潟歯学部 \\ 第二口腔解剖学教室
}

Dr. Sumio Yoshie

Department of Oral Anatomy

Nippon Dental University, Niigata

1-8 Hamaura-cho

Niigata, 951 Japan 